\title{
Literature Review: Mathematical Creative Thinking Ability, and Students' Self Regulated Learning to Use an Open Ended Approach
}

\author{
Damsir Ali, Zubaidah Amir MZ*, Kusnadi, \& Rian Vebrianto \\ Master of Teacher Education Study Program at Madrasah Ibtidaiyah State Islamic University Sultan Syarif Kasim Riau, Indonesia, 28293 \\ *Corresponding author: zubaidah.amir@uin-suska.ac.id | Phone Number: +6281365702034
}

\section{ARTICLE HISTORY}

Received: 14 November 2020

Revised: 11 March 2021

Accepted: 16 April 2021

\section{KEYWORDS}

Open Ended Approach; Creative Thinking; Self-Regulated Learning; Mathematics Learning;

\begin{abstract}
The ability to think creatively and self-regulated learning is very important in learning mathematics, in order to train students to develop their creativity. But in reality, mathematics learning that is currently happening has not been able to develop mathematical creative thinking skills and increase students' self-regulated learning. The purpose of this study is to examine the relationship between the open-ended approach and the ability to think creative mathematically and self-regulated learning and how to implement it in school in the perspective of literature review. The type of research used is literature review, where articles are collected using search engines such as EBSCO, Science direct, and Scopus. Based on the articles collected, the results show that: 1. Mathematics learning to use an open-ended approach has an effect on increasing students 'creative thinking skills and self-regulated learning, 2. The open-ended approach is higher in increasing students' creative thinking abilities compared to using a conventional approach, 3 . The open-ended approach to learning has the following steps: a) the teacher organizes students in learning activities; b) the teacher exposes students to open problems; c) the teacher guides and directs students in solving problems with various solutions and various answers; d) students present their work and compare with the work of other students in front of the class; and e) students conclude the subject matter, which is guided by the teacher. 4 . To apply open-ended learning, it is necessary to prepare learning that requires high creativity for a teacher.
\end{abstract}

This is an open access article under the CC-BY-SA license.

\section{INTRODUCTION}

Creative thinking skills in math learning are essential to foster a higher level of thinking for students. According to Winkel creative thinking is a thought that produces creative ideas or new, original, independent and imaginative ways of thinking (Agustina \& Noor, 2016). Ruseffendi says creative humans are human beings who are able to benefit others not just for themselves (Meiliana \& Aripin, 2019). This shows that developing creative thinking skills towards students is very important to train them to use their creativity early on and well formed into the future.

In addition to developing creative thinking skills, students must also have Self-Regulated Learning that trains students to learn independently. This is in line with research that says that self-regulated learning is a learning strategy that is able to make students independent in learning and improve their academic achievement (Dinata et al., 2016). Students who study self-learning means that they are not self-learning, but that high self-regulated learning can make students achieve their learning goals well.

But the reality is, mathematics learning that occurs today has not been able to optimally develop the ability to think creatively mathematically and improve the self-regulated - learning of students. This is reinforced from the results of observations and interviews of writers with teachers in several schools in Marpoyan-Damai sub-district of Pekanbaru city. The results showed that the teacher's learning was too referring to the book, because according to this teacher it was learning that was in accordance with the direction of the 2013 curriculum, but they did not consider whether the designed learning was capable of fostering the ability to think creatively mathematically and self-regulated learning students. This is the problem with math learning, math learning that should be able to encourage students to improve their creative thinking and self-regulated learning skills but not succeed to the fullest.

The low ability to think creatively mathematically and self -regulated learning is not only due to difficult math learning, but also due to other factors such as students themselves, teachers, learning strategies used, and learning environments related to each other (Waluyo, 2018). The factors that can affect students' creative thinking skills and self-regulated learning are the need for learning innovation. The innovation can be the application of a learning approach that is able to give students the opportunity to express their ideas and ideas. According to 
Sagala teachers are as a source of learning, determinants of learning methods and models, as well as assessors of student learning progress to make learning more effective and efficient to achieve the learning goals themselves (Wanelly \& Fauzan, 2020). Therefore, a teacher must have a learning approach that suits the student's condition so that students feel interested in the learning presented by the teacher, thus learning will be able to improve the creative thinking skills of mathematical and self -regulated learning students. One of the appropriate learning approaches to addressing the problem of mathematical creative thinking skills and self-regulated learning is the Open-Ended approach. An approach that gives students the opportunity to gain knowledge, experience, discover, recognize and solve problems with multiple techniques (Zarkasyi, 2015).

Through this paper, the author aims to examine the open ended approach, its relationship to Mathematical Creative Thinking ability and Self-Regulated Learning, and how it is implemented in the perspective of review literature. The benefits of this research are expected to include innovations and guidelines in choosing effective methods for the mathematical learning process.

\section{RESEARCH METHOD}

The method used is library research. Literature-based research, which is an international and national literature search

Table 1. Details of the manuscript to be analyzed

\begin{tabular}{|c|c|c|}
\hline Author (year) & Title of Manuscript & Manuscript Identity \\
\hline $\begin{array}{l}\text { Widya Wanelly dan } \\
\text { Ahmad Fauzan (2020) }\end{array}$ & $\begin{array}{l}\text { Pengaruh Pendekatan Open-Ended dan Gaya Belajar Siswa terhadap Kemampuan Berpikir } \\
\text { Kreatif Matematis. }\end{array}$ & $\begin{array}{l}\text { Jurnal Basicedu, Vol. 4, No.3, } \\
\text { HIm. 523-533 }\end{array}$ \\
\hline $\begin{array}{l}\text { Samsul Palah, M. Maulana, } \\
\text { dan Ani Nur Aeni (2017) }\end{array}$ & $\begin{array}{l}\text { Pengaruh pendekatan open-ended berstrategi M-RTE terhadap kemampuan berpikir kreatif } \\
\text { matematis siswa pada materi persegi panjang }\end{array}$ & $\begin{array}{l}\text { Jurnal Pena Ilmiah, Vol.2, No.1, } \\
\text { HIm. 1161-1170. }\end{array}$ \\
\hline $\begin{array}{l}\text { Egi Agustian, Atep Sujana, } \\
\text { dan Yedi Kurniadi (2015) }\end{array}$ & $\begin{array}{l}\text { Pengaruh Pendekatan Open-Ended terhadap Kemampuan Berpikir Kreatif Matematis Siswa } \\
\text { Sekolah Dasar Kelas V (2015) }\end{array}$ & $\begin{array}{l}\text { Jurnal Mimbar Sekolah Dasar, Vol. } \\
\text { 2, No. 2, HIm. 234-242. }\end{array}$ \\
\hline Ardi waluyo (2018) & $\begin{array}{l}\text { Pengaruh Pendekatan Open-Ended terhadap Kemampuan Berpikir Kreatif Siswa Dalam Mata } \\
\text { Pelajaran Matematika Di Sekolah Dasar. }\end{array}$ & $\begin{array}{l}\text { Jurnal Pendidikan Sekolah Dasar. } \\
\text { Vol. } 5 \text {, No. 1, HIm. 105-119. }\end{array}$ \\
\hline $\begin{array}{l}\text { Ni Pt. Rika Ardiyanti, I Md. } \\
\text { Suarjana, Ni Nym. } \\
\text { Garminah (2013) }\end{array}$ & $\begin{array}{l}\text { Pengaruh Model Pembelajaran Matematika Berorientasi Open-Ended Problem terhadap } \\
\text { Kemampuan Berpikir Kreatif Siswa Pada Mata Pelajaran Matematika Kelas IV SD. }\end{array}$ & $\begin{array}{l}\text { Jurnal Mimbar PGSD UNDIKSILA, } \\
\text { Vol. } 1 \text {, No.1. }\end{array}$ \\
\hline Japemar (2019) & $\begin{array}{l}\text { Peningkatan Kompetensi Kognitif Matematika Siswa Menggunakan Pendekatan Open Ended } \\
\text { di Kelas X SMA Negeri } 1 \text { Ulakan Tapakis. }\end{array}$ & $\begin{array}{l}\text { Jurnal Penelitian Dan Kajian Ilmiah, } \\
\text { Vol. } 13 \text {, No. } 11, \mathrm{HIm} .28-32\end{array}$ \\
\hline $\begin{array}{l}\text { Firdaus, Abdur Rahman } \\
\text { As'ari, Abd. Qohar (2016) }\end{array}$ & $\begin{array}{l}\text { Meningkatkan Kemampuan Berpikir Kreatif Matematis Siswa SMA Melalui Pembelajaran } \\
\text { Open-Ended Pada Materi SPLTV }\end{array}$ & $\begin{array}{l}\text { Jurnal Pendidikan, Vol. } 1 \text { No. 2, Bln } \\
\text { Februari, Thn 2016, Hal 227-236 }\end{array}$ \\
\hline Suhandri (2013) & $\begin{array}{l}\text { Meningkatkan Kemampuan Berpikir Kreatif Matematis Siswa melalui Pendekatan } \\
\text { Open-ended. }\end{array}$ & $\begin{array}{l}\text { Jurnal Gamatika, Vol. 3, No. 2, } \\
\text { HIm. 140-146. }\end{array}$ \\
\hline $\begin{array}{l}\text { Nenden Faridah, Isro'atun } \\
\text { dan Ani Nur Aeni (2016) }\end{array}$ & $\begin{array}{l}\text { Pendekatan Open Ended Untuk Meningkatkan Kemampuan Berfikir Kreatif Matematis Dan } \\
\text { Kepercayaan Diri Siswa. }\end{array}$ & $\begin{array}{l}\text { Jurnal Pena Ilmiah, Vol.1, No.1, } \\
\text { Hal. 1061-1070 }\end{array}$ \\
\hline Khaspul Khairobi (2017) & $\begin{array}{l}\text { Pengaruh Pendekatan Open-Ended Terhadap Kemampuan Komunikasi dan Self Regulated } \\
\text { Learning Peserta Didik Kelas IV Mata Pelajaran Ilmu Pengetahuan Alam (IPA) Di MI Ismariah } \\
\text { Al-Quraniyyah. }\end{array}$ & $\begin{array}{l}\text { Jurnal Ekp, Vol.13, No.3, } \\
\text { 1576-1580. }\end{array}$ \\
\hline $\begin{array}{l}\text { Siti Salamah Br Ginting } \\
\text { (2019) }\end{array}$ & $\begin{array}{l}\text { Peningkatan Kemampuan Berpikir Kreatif Matematis dan Kemandirian Belajar Siswa SMP } \\
\text { Ar-Rahman Medan Melalui Pembelajaran Open-Ended Berbasis Brain-Gym. }\end{array}$ & $\begin{array}{l}\text { Jurnal AXIOM: Vol. VIII, No. 1, } \\
\text { Januari - Juni 2019, P- ISSN : } 2087 \text { - } \\
\text { 8249, E-ISSN: } 2580-0450\end{array}$ \\
\hline $\begin{array}{l}\text { Suriyani, Hasratuddin, H., } \\
\text { \& Asmin, A. (2015). }\end{array}$ & $\begin{array}{l}\text { Peningkatan Kemampuan Berpikir Kreatif dan Kemandirian Belajar Siswa MTs Negeri } 2 \\
\text { Medan Melalui Pembelajaran Matematika dengan Pendekatan Open-Ended. }\end{array}$ & Jurnal Tabularasa, Vol.12 No. 3. \\
\hline \multicolumn{3}{|c|}{$\begin{array}{ll}\text { SCUSSION } & \text { ended approach to mathematics subjects is experimentation, } \\
& \text { class action research (PTK) and literature. The percentage of use } \\
& \text { of experimental design, PTK and literature found in the } \\
& \text { manuscript can be seen in Tabel 2. }\end{array}$} \\
\hline
\end{tabular}

Based on review results, the research design used in the open-

Table 2. Percentage Of Research Design

\begin{tabular}{lccl}
\hline \multicolumn{1}{c}{ Research Design } & Amount & Percentage & Table 2. Percentage Of Research Design \\
\hline $\begin{array}{l}\text { Eksperimen } \\
\text { (Experiment) }\end{array}$ & 9 & $75 \%$ & $\begin{array}{l}\text { Widya Wanelly, Ahmad Fauzan (2020), Samsul Palah, M. Maulana, dan Ani Nur Aeni (2017), Egi Agustian, } \\
\text { Atep Sujana, dan Yedi Kurniadi (2015), Ni Pt. Rika Ardiyanti, I Md. Suarjana, dan Ni Nym. Garminah } \\
\text { (2013), Suhandri (2013), Nenden Faridah, Isro'atun dan Ani Nur Aeni (2016), Khaspul Khairobi (2017), Siti } \\
\text { Salamah Br Ginting (2019). Suriyani, Hasratuddin, H., \& Asmin, A. (2015). }\end{array}$ \\
\hline Class Action Research & 2 & $16,7 \%$ & Japemar (2019) dan Firdaus, Abdur Rahman As'ari, Abd. Qohar (2016) \\
\hline Literature Research & 1 & $8,3 \%$ & Ardi waluyo (2018) \\
\hline & 12 & $100 \%$ & \\
\hline
\end{tabular}


Table 2 shows that research that adopts an open-ended approach uses more experimental research design i. e. 9 manuscripts with a percentage of $75 \%$, grade 2 action research scripts with a percentage of $16.7 \%$ and literature research 1 manuscript with a percentage of $8.3 \%$. The design of the experiment research is more widely found because the study aims to find out the effect of treatment on controlled conditions (Sugiyono, 2011).

\subsubsection{Education Level Where the Application of Open-Ended Approach}

From review results, the open-ended approach is applied to the education level of elementary, junior high and high school. The percentage of open-ended approach application at the level of elementary, junior high and high school education can be seen in Tabel 3.

Table 3. Education Level that Implements an Open-Ended Approach

\begin{tabular}{cccl}
\hline Education Level & Number of Manuscripts & Percentage & \multicolumn{1}{c}{ Researchers } \\
\hline SD & 7 & $58,3 \%$ & $\begin{array}{l}\text { Widya Wanelly , Ahmad Fauzan (2020), Samsul Palah, M. Maulana, dan Ani Nur Aeni (2017), } \\
\text { Egi Agustian, Atep Sujana, dan Yedi Kurniadi (2015), Ni Pt. Rika Ardiyanti, I Md. Suarjana, dan } \\
\end{array}$ \\
& & $\begin{array}{l}\text { Ni Nym. Garminah (2013), Ardi waluyo (2018), Nenden Faridah, Isro'atun dan Ani Nur Aeni } \\
(2016), \text { Khaspul Khairobi (2017), }\end{array}$ \\
\hline SMP & 3 & $25 \%$ & Siti Salamah Br Ginting (2019), Suhandri (2013), Suriyani, Hasratuddin, H., \& Asmin, A. (2015). \\
\hline SMA & 2 & $16,7 \%$ & Japemar (2019), Firdaus, Abdur Rahman As'ari, Abd. Qohar (2016), \\
\hline & 12 & $100 \%$ & \\
\hline
\end{tabular}

Table 3 shows that research into creative thinking skills and self - regulated learning using an open-ended approach is more widely researched in elementary school, namely 7 scripts with a percentage of $58.3 \%$, in junior high school 3 scripts with a percentage of $25 \%$ and in high school 2 scripts with a percentage of $16.7 \%$. This shows that the importance of creative thinking and self-regulated learning is established early on in elementary school, but the selection of classes should be more precise because creative thinking is a high level of thinking.

\subsubsection{The Influence of the Ope- Ended Approach}

From review results, the open-ended approach has an influence on improving the creative thinking skills of mathematical and self-regulated learning students. The influence of open ended can be seen on Table 4 .

Table 4. Summary of Research Results

\begin{tabular}{|c|c|}
\hline Authors (year) & Result 192 \\
\hline $\begin{array}{ll}\text { Widya Wanelly dan } & \text { Ahmad } \\
\text { Fauzan (2020) } & \end{array}$ & $\begin{array}{l}\text { The results of the Creative Thinking Skills Test of grade IV students of SD Kecamatan Lubuk Basung with an open-ended approach } \\
\text { are better than students using conventional approaches. Students' creative thinking abilities are auditorial learning styles, visual } \\
\text { learning styles, and kinetic learning styles using an open-ended approach better than students using conventional approaches. } \\
\text { The results show that the open ended- approach exerts a better influence than conventional approaches in improving students' } \\
\text { mathematical creative thinking skills. }\end{array}$ \\
\hline $\begin{array}{l}\text { Samsul Palah, M. Maulana, } \\
\text { dan Ani Nur Aeni (2017) }\end{array}$ & $\begin{array}{l}\text { M-RTE's open-ended strategy approach can have a positive impact on mathematical creative thinking skills. This is seen in the } \\
\text { improvement of students' mathematical creative thinking skills in the experiment class. The average pretest score obtained in } \\
\text { the experiment class was } 33.33 \text { while the average posttest score obtained was } 41.11 \text {. Thus, an } N \text {-gain of } 0.10 \text { is obtained. After } \\
\text { the average difference test, the results showed that there was an average difference between the pretest and posttest values. } \\
\text { Based on this, it can be concluded that the positive influence given M-RTE's open-ended approach to mathematical creative } \\
\text { thinking skills occurs significantly. }\end{array}$ \\
\hline $\begin{array}{l}\text { Egi Agustian, Atep Sujana, } \\
\text { dan Yedi Kurniadi (2015) }\end{array}$ & $\begin{array}{l}\text { Both open-ended and conventional approaches can improve the mathematical creative thinking skills of elementary school } \\
\text { students on cube and beam materials. But learning using an open-ended approach is better. This can be based on the results of } \\
\text { the 3rd hypothesis test by using the Paired Sample T-test. The results of the test received sig }(2 \text { tailed) results of } 0.000 \text {, smaller } \\
\text { than the level of significance }(0.000<0.05) \text {, then } \mathrm{HO} \text { rejected or } \mathrm{H} 1 \text { accepted, so that from the results of the test it can be } \\
\text { known that there is a significant average difference between the results of } \mathrm{N} \text {-Gain the mathematical thinking skills of students } \\
\text { of the experimental group and control on the learning of mathematics with cube volume materials and beams. }\end{array}$ \\
\hline Ardi waluyo (2018) & $\begin{array}{l}\text { Learning mathematics using an open- ended approach can influence the increasing creative thinking of elementary school } \\
\text { students. With an open-ended approach learning is more interesting and fun so that the learning goals will be achieved } \\
\text { optimally. The open ended -approach is higher in improving students' creativity thinking abilities than using a conventional } \\
\text { approach. To implement open- ended learning, it is necessary to prepare a learning that requires the creativity of a teacher. } \\
\text { Therefore, learning mathematics using an open-ended approach is very effective if applied. }\end{array}$ \\
\hline $\begin{array}{l}\text { Ni Pt. Rika Ardiyanti, I Md. } \\
\text { Suarjana, Ni Nym. Garminah } \\
(2013)\end{array}$ & $\begin{array}{l}\text { The results showed there were significant differences in students' creative thinking abilities between the group of students who } \\
\text { were learned and the open- ended problem- oriented Mathematics learning model and the group of students who were learned } \\
\text { by conventional learning models. The results showed tcount } 10.43>t_{\text {table }} 1,67 \text {. This significant difference can also be seen from } \\
\text { the average score achieved by the group of students learned with the open-ended problem- oriented Mathematics learning } \\
\text { model is } 46.34 \text { and the average score of the group of students learned by conventional learning model is } 35.91 \text {. This means that } \\
\text { the creative thinking skills of students learned using the open-ended problem-oriented mathematics learning model are better } \\
\text { than the creative thinking skills of students who are learned using conventional learning models. }\end{array}$ \\
\hline Japemar (2019) & $\begin{array}{l}\text { Based on the results of analysis from two cycles of research, there was an increase in the percentage of cognitive competency } \\
\text { completion in cycle I by } 57.15 \% \text { increased to } 85.71 \% \text { in cycle II. The increase also occurred in the average student grade of } 68.93 \\
\text { to } 80.60 \text {. Classically the completed learning outcomes of students have achieved a set success of } 70 \% \text {. The increase occurred } \\
\text { because of the use of an open ended-approach. Students in learning have a lot of experience to find something to answer } \\
\text { problems. Because of these problems that students often experience in daily life. Based on the results of the study obtained the } \\
\text { following conclusion: Learning using an open ended-approach can improve the cognitive competency of mathematics students } \\
\text { grade X SMA N } 1 \text { Ulakan Tapakis. The results of the analysis of research data using the open ended- approach in grade X of SMA } \\
\text { Negeri } 1 \text { Ulakan Tapakis can be stated cognitive competency of students who achieved a complete percentage of } 57.15 \% \text { in cycle } \\
\text { I increased to } 80.60 \% \text { in cycle II. }\end{array}$ \\
\hline $\begin{array}{l}\text { Firdaus, Abdur Rahman } \\
\text { As'ari, Abd. Qohar (2016) }\end{array}$ & $\begin{array}{l}\text { The results of study with the application of open ended-approach learning show that in cycle I has not improved the creative } \\
\text { thinking skills of students. Implementation of cycle II the average observation results of teacher and student activity scores of } \\
3.66 \text { and } 3.67 \text { are on good criteria, the percentage of final results of the quiz at the end of each study, namely fluency (100\%), } \\
\text { flexibility }(90.33 \%) \text { and novelty }(72.58 \%) \text {, meaning fluency, flexibility, novelty are on the minimum criteria quite creatively. } \\
\text { Furthermore, the data of students' creative thinking assessment results are obtained from the final test results of cycle II. } \\
\text { Overall students have achieved the minimum criteria quite creatively, which is } 25 \text { students with a percentage of success (PK) } \geq \\
65 \text { is } 80.65 \% \text {. Then there are } 6 \text { students with a percentage of success (PK) < } 65 \text {, which is } 19.35 \% \text {. Based on the determined } \\
\text { indicators of success, that the implementation of learning using an open ended-approach in cycle II can already improve } \\
\text { students' mathematical creative thinking skills. }\end{array}$ \\
\hline
\end{tabular}




\begin{tabular}{|c|c|}
\hline Authors (year) & Result \\
\hline Suhandri (2013) & $\begin{array}{l}\text { After the learning process there was an improvement in the mathematical creative thinking skills of the experimental group } \\
\text { students who used learning with an Open-ended approach better than the control group or learning using conventional learning. } \\
\text { Meanwhile, information about improving students' creative thinking skills after the learning process of teaching in the } \\
\text { experiment group and control group was obtained from normalized gain scores, which is data obtained from the difference } \\
\text { between pretest and posttest scores. Based on observation and dissemination of questionnaires on the issue of students' } \\
\text { attitudes towards open-ended approach learning obtained data, overall the attitude of students is positive towards an } \\
\text { open-ended approach to improving the ability of mathematical creative thinking. This can be seen from the average student's } \\
\text { attitude score towards mathematical creative thinking of } 2.94 \text {. This score is greater than the neutral attitude score of } 2.38 \text {. } \\
\text { Similarly, it is seen that students in general expressed a fondness for an open-ended approach to improving mathematical } \\
\text { creativity, the results showed } 83 \% \text { of experimental graders favored the use of an open-ended approach and could improve their } \\
\text { creative thinking skills }\end{array}$ \\
\hline $\begin{array}{l}\text { Nenden Faridah, Isro'atun } \\
\text { dan Ani Nur Aeni (2016) }\end{array}$ & $\begin{array}{l}\text { The results of the study say that the open ended-approach affects students' creative thinking abilities. It can be seen in the } \\
\text { pretest class of experiments obtained an average score of } 32.3 \text { medium average posttest value of } 62.4 \text {. Based on these values, } \\
\text { the average difference between the experiment class pretest and posttest values is } 30.1 \text { where the posttest is better than the } \\
\text { pretest. The average difference in grades in both classes showed that the average grades in the experiment class were greater. } \\
\text { Based on statistical tests state that the open ended-approach is better than conventional approach in improving students' } \\
\text { mathematical creative thinking skills. }\end{array}$ \\
\hline Khaspul Khairobi (2017) & $\begin{array}{l}\text { Based on hypothesis calculations The High and Low Self-Regulated Learning Questionnaire showsthat } \mathrm{t}_{\text {count }}=41,214 \text { while- } t_{\text {table }} \\
=2,037 \text { with } \mathrm{a}=0.05 \text {. Thus, the calculation results show thitung } \geq \mathrm{ttabel} \text { (H0 rejected and } \mathrm{H} 1 \text { accepted). Meaning there is a } \\
\text { differrences in Self-Regulated Learning between students who are taught using open ended-approach compared to conventional } \\
\text { approach in grade IV MI Ismariyyah Al-Quraniyah Rajabasa Bandar Lampung. }\end{array}$ \\
\hline $\begin{array}{l}\text { Siti Salamah Br Ginting } \\
\text { (2019) }\end{array}$ & $\begin{array}{l}\text { After treatment was given in the experiment class, namely with brain-gym-based open-ended learning there was a significant } \\
\text { improvement in mathematical creative thinking skills compared to the control classes given expository learning. Based on the } \\
\text { results of the study, the average gain index for each aspect of mathematical creative thinking in the experiment class is higher } \\
\text { than the control class that is on the smooth thinking aspect of } 0.758>0.587 \text {, flexible thinking aspect } 0.833>0.313 \text {, original } \\
\text { thinking aspect } 0.569>0.297 \text {, elaborative thinking aspect } 0.531>0.380 \text {, and for the overall aspect } 0.695>0.474 \text {. The results } \\
\text { showed that the average increase in student learning self-reliance taught with brain-gym-based open-ended learning was higher } \\
\text { than the average increase in student self-reliance skills taught with expository learning. }\end{array}$ \\
\hline $\begin{array}{l}\text { Suriyani Suriyani, Hasruddin } \\
\text { Hasratuddin, Asmin Asmin }\end{array}$ & $\begin{array}{l}\text { The results showed that (1) improved creative thinking skills of students taught using math learning with an Open-Ended } \\
\text { approach were better than those taught with conventional learning, (2) improved self-regulated learning using math } \\
\text { learning with a better Open-Ended approach than those taught with conventional learning, (3) there is no interaction between } \\
\text { the learning approach and the student's early math ability to improve students' creative thinking skills, and (4) there is no } \\
\text { interaction between the learning approach and the student's initial math ability to improve the student's self-regulated } \\
\text { learning. Based on the research findings open ended-approach can be recommended to be one of the learning approaches used } \\
\text { in the main school to achieve creative thinking competency and learning independence. }\end{array}$ \\
\hline
\end{tabular}

Based on the some of the study results that have been presented on the influence of open-ended approach to the ability of mathematical creative thinking and self-regulated learning students, it can be seen that the creative thinking ability of students who follow learning with an open-ended approach is higher than in students who follow conventional learning. The open ended-approach also has a positive influence on students' self-regulated learning. Learning mathematics with an open-ended approach can improve students' creative thinking skills. In this case, mathematics learning with an open-ended approach can be applied by teachers who teach in schools to improve the creative thinking skills of mathematical and self -regulated learning students. Because the open-ended approach gives students breadth in answering questions. In the application of an open ended-approach teachers should prepare a proper and appropriate learning plan. Written tests used to assess a student's ability to think creatively should also useopen-ended problems or problems. With open-ended questions, it can open insights so that students can answer questions or solve problems given in various ways.

\subsection{Discussion}

\subsubsection{Open-Ended Approach}

The open-ended approach is an innovation in mathematics education that was first conducted by mathematicians in Japan. This approach is the result of research in 1997 conducted by Shimada, Toshio Sawada, Yoshiko Yashimoto, and Kenichi Shibuya (Euis Eti Rohati et al.,2019). The open-ended approach is an approach that helps students do problem solving creatively and appreciate the diversity of thinking that presents a problem that has more than one method or solution and may also have many correct answers. The purpose of open ended is not to get an answer, but rather to focus on how to get to the answer. The Open-ended approach according to Shimada and Becker is "a learning strategy that creates interest and stimulates creative math activities in the classroom through the collaborative work of students." Lessons using open problem solving put more emphasis on the process of problem solving activities than focusing on results" (Suhandri, 2013). The Open ended approach is a learning approach by presenting a problem that has more than one answer or method of solving(Zarkasyi, 2015). The open-ended approach starts with a view of how to objectively evaluate students' abilities and high-level math thinking. In order for mathematics to beloved and studied by all students, then closed problems that demand one correct answer should be replaced with open ended-problems. An open ended-approach is a learning approach that starts with introducing or confronting students on open-ended issues. The problem of open ended is a problem formulated has many correct answers (Ruslan \& Santoso, 2013). With this activity is expected to bring students to answer problems in many ways, thus inviting the intellectual potential and experience of students in the process of finding something new.

An open-ended approach is one that helps students do problem solving creatively and appreciate the diversity of thinking that presents a problem that has more than one method or solution and may also be with many (correct) answers. This approach provides students with the opportunity to gain knowledge, experience, discover, recognize, and solve problems with some of these techniques and approaches are expected to be facilitators in developing and stimulating students' creative thinking and problem-solving skills. With this expectation, mathematics learning with an open-ended approach was chosen in this study to look at differences in students' creative thinking skills and mathematical problem solving.

The application of open-ended learning with stages: 1) organizes students in learning activities by forming student learning groups of 4-6 people; 2) present an open problem to a group of students in the form of a student activity sheet; 3 ) direct students in solving the problems presented until the settlement is obtained in a variety of ways; 4) present and compare the work of each group in front of the class; 5) 
conclude the materials/findings obtained in learning activities guided by teachers (Lubis et al., 2019). Furthermore, Huda argues that the steps in the Open ended learning strategy are: 1) confronting students on open problems; 2) guide students to find patterns in constructing their own problems; 3) let students solve problems with various solutions and diverse answers; and 4) ask students to present their findings (Kurniati $\&$ Astuti, 2017). Based on the opinions of the two experts on the stage of open-ended learning, both give students the opportunity to investigate various strategies and ways that are believed to be in accordance with the ability to elaborate problems, the difference is only in the grouping of students. The first opinion is the opinion of Becker who implements open -ended learning in groups.

The open-ended approach can train and foster originality of ideas, creativity, high cognitive, critical, communication interaction, sharing, openness and socialization. Thus, the open-ended approach will be able to give students the opportunity to answer various problems through various strategies or means. This is reinforced by the assertion that learning activities with an open ended approach should lead students in answering problems in many ways and also have the right answers (Lestari et al., 2016); (Kurniati \& Astuti, 2017). In addition, with this open-ended approach, students will be directly motivated to solve a problem in various ways with their friends as well as with teachers.

The open ended approach has the advantage of encouraging creative activities from students and thinking mathematically on simultaneous problem solving (Wanelly \& Fauzan, 2020). This approach provides students with the opportunity to gain knowledge, experience, discover, recognize, and solve problems with several techniques and stimulate students' creative thinking and problem-solving skills (Lubis et al., 2019). Because open-ended problems have more than one solution, teachers need to create an assessment Criteria. Sawada (Muhsinin, 2014) has given criteria in assessing the results of students' work, namely as follows: 1 . Proficiency, defined as the ability to use several methods of completion. 2. Flexibility, is an opportunity for students to answer correctly for some similar questions. 3. Authenticity, this category is intended to measure the authenticity of students' ideas in providing correct answers. The Open-ended problem has a very close relationship with creativity. Because in solving open-ended problems requires creative thinking skills and problem solving. The main purpose of students faced with open-ended problems is not to get answers but to emphasize more on how to get to an answer (Suherman, 2019). Thus, an open-ended approach is not only one way or method of obtaining answers, but several or many ways of solving mathematical problems.

Learning that uses an open-ended approach can be interpreted as a collection of evidence or learning results of students that show the effort, development, learning achievement of students over time and from one subject to another. Therefore, students can succeed in learning because more are trained to search for or find their own information (Andriani \& Madio, 2013). Learning with an Open-Ended approach starts by giving students open problems. Learning activities should lead and lead students in answering problems in many ways as well as perhaps also with many (correct) answers, thereby stimulating students' intellectual abilities and experience in the process of discovering something new (Andriani \& Madio, 2013). Both opinions are in line with the advantages of the open ended approach, among others: 1) students take a more active part in learning, and often express their ideas; 2) students have more opportunities to use their knowledge and mathematical skills; 3) students with low abilities can react to problems in some significant way of their own; 4) encourage students to give evidence; and 5) students have a rich and happy experience of their discoveries and receive the consent of friends (Akbar et al., 2017). Furthermore, the open-ended approach is intended to allow students to be more creative in developing a mindset in solving the given problem and fostering an independent and responsible attitude in solving the given problem (Amir \& Risnwati, 2014). Based on some of these opinions, it can be understood that the purpose of the open-ended approach in math learning is to improve the creative thinking skills of mathematics simultaneously in order to develop to the maximum, giving students the freedom to think in making progress solving according to their abilities, attitudes and interests through various strategies and ways that it believes in solving problems thus shaping the student's mathematical intelligence.

An open-ended problem is an open problem that has many correct answers. These open problems are grouped into three types, namely: (1) problems that can be solved in varying ways, (2) problems that have varied answers, and (3) problems that can be developed by changing the condition of the previous problem (Putri, 2017). Giving teachers open ended problem problems is expected to explore student reasoning and help teachers evaluate the diversity of students' knowledge and can encourage students' creative thinking.

\subsubsection{Creative Thinking}

Creative thinking is the embodiment of high-level thinking. Creative thinking is at the highest level of thinking after retention, basic thinking, and critical thinking. Creative thinking is also included in reasoning. Thus, to achieve creative thinking these four types of thinking must be mastered. Creative thinking can be defined as a combination of logical thinking and divergent thinking based on intuition but has a realized purpose (Pehkonen \& Helsinki, 1997). In particular it can be said that creative thinking as a unit or a combination of logical thinking and divergent thinking in order to produce something new. Something new is one indication of creative thinking in mathematics (Ginting, 2019). Creative thinking as a combination of logical thinking and divergent thinking based on intuition in consciousness. Therefore, creative thinking involves logic and intuition together.

Mathematical creative thinking skills are part of life skills that need to be developed especially in the face of an increasingly tight era of information and competitive atmosphere. Therefore, the creative thinking skills of mathematics are very important for students to deal with changes and be able to produce something new in the future. Another ability that students should have besides creative thinking is the ability to be independent, which is attitudes and behaviors that do not easily rely on others in completing tasks.

Munandar explains the sense of creative thinking is the ability to find many possible answers to a problem, where the emphasis is on quantity, preciseness, and diversity of answers (Purwaningrum, 2016). This understanding indicates that a person's creative thinking ability is higher, if he or she is able to show many possible answers to a problem. However, all of those answers must be appropriate and appropriate, in addition the answers must vary (Yuliana, 2015). In general, creative children have a high curiosity, have a wide interest, and love creative 
passions and activities. Creative children and adolescents are usually quite independent and have confidence. They are more likely to take risks than children in general, meaning that in doing something that for them is very meaningful, important, and likable, they don't care too much about criticism or ridicule from others.

The development of creative thinking skills is one of the main focuses in mathematics learning. Because mathematics materials are so complex and in combination with each other, mathematics learning needs to be designed in such a way as to potentially develop students' creative mathematical thinking skills. This mathematical creative thinking ability must continue to be developed and trained. One of them is applying learning that can give students the opportunity to express and develop their ideas freely but still under the guidance of teachers as facilitators (Akbar et al., 2017). Dengan thus, guru can train students' mathematical creative thinking skills in a learning atmosphere in the classroom.

Creative thinking has two important components: logic and intuition (Nurhikmayati \& Sunendar, 2020). According to Evans creative thinking is detected in four elements: sensitivity, smoothness, flexibility, and authenticity (Dahlan et al., 2017); (Muhtadi \& Sukirwan, 2017). The sensitivity referred to here is sensitivity to problem situations concerning the ability to identify problems, being able to distinguish facts that are irrelevant to the problem, including distinguishing relevant concepts about the actual problem. This sensitivity also includes what a person feels in connection with an identified problem, such as a related concept, an appropriate strategy for solving the problem. The flexibility of intent here refers to the ability to build diverse ideas. Flexibility is as a variation that shows the wealth of ideas and efforts of the person concerned in building ideas towards the expected solution. Authenticity is the ability to generate unusual ideas and solve problems in unusual ways. This authenticity appears in a variety of forms, from simple or informal to later can be developed into more complete.

Creative thinking contains aspects of cognitive, affective, and metacognitive skills (Widiawati et al., 2019); (MZ, 2017). These cognitive skills relate to the ability to identify problems and opportunities, compose good and different questions, identify relevant and irrelevant data, productive problems and opportunities. In addition, this ability is also related to the ability to generate many ideas, produce different ideas, as well as new products or ideas, examine and assess the relationship between options and alternatives, change old mindsets and habits, build new relationships, expand and update plans or ideas. Some steps to creative thinking are: asking questions, transforming information into new and open minded views, finding relationships between different things, looking at each other, making something new and different, and considering intuition (Sariningsih \& Herdiman, 2017). Creative thinking can also be interpreted as a mental activity that a person uses to build a new idea or thought. Another opinion of Pehkonen, he views creative thinking as a combination of logical thinking and divergent thinking based on intuition but still in consciousness (Amidi \& Zahid, 2016). The intent of divergent thinking itself is to provide an assortment of possible answers to the same question.

According to Munandar, creative thinking has 5 indicators, further, creative thinking skills developed in the form of description questions with indicators of smoothness, flexibility, authenticity and elaboration (I. W. S. Putri et al., 2017). Other opinions also say that creative thinking indicators that can be used in research include: 1) fluency, 2) flexibility, and 3) novelty (Rahmazatullaili et al., 2017). Creative thinking skills are indispensable to students given that today science and technology are evolving rapidly and enabling anyone to obtain information quickly and easily from sources around the world.

Characteristics of creative thinking include: 1) Curiosity characterized by investigation, asking, seeking a deeper understanding, 2) smoothness to form a number of ideas, 3) authenticity, 4) the ability to enrich and develop a product or idea or situation so as to be more interesting, 5) the ability to imagine, and 6) flexible thinking skills that mean finding many different alternatives resulting in a variety of ideas, answers or questions that vary (Susilo, 2015). Thus, students are triggered by their curiosity to master learning materials, easy to understand newly acquired concepts so as to bring forth a new set of concepts that can give understanding to students.

One approach that is able to provide solutions in improving the quality of math learning, especially the ability to think creatively mathematically is an open-ended approach. This is because this approach starts with presenting a problem to students who have the correct solution of more than one (Soeyono, 2013). It is also suggested by Sewada that the open-ended approach, teachers are able to provide a problem situation to students whose solutions can be obtained in various ways (Utami et al., 2020). In addition, through open-ended, students' understanding can be developed in teaching mathematics in schools (Mihajlović \& Dejić, 2015). This is one way to improve the creative thinking skills of students, where that mathematical creative thinking trains students to see a problem from a different point of view and connect it to their knowledge so as to produce varied solutions that are new to open mathematical problems.

Shimada defines learning with an open-ended approach starting with presenting open-ended problems first and then learning is processed by using many correct answers to give students the experience of discovering something new (Euis Eti Rohati dkk, 2019) (Rudyanto, 2016). With an open-ended approach in mathematics subjects, an open math problem is required. According to Japar learning with an open-ended approach begins by giving open problems to students (Muhsinun, 2013). Open problems will make students look for open solutions as well. Solutions or troubleshooting can be searched in a variety of ways. This, which makes the open-ended approach make students creative in learning mathematics. According to Coney it takes open questions to apply an open-ended approach to math learning (Rudyanto, 2016). The open questions used in the open-ended approach have the following characteristics: 1) involve important mathematics; 2) produce diverse answers; 3) requires communication; and 4) clearly stated (Waluyo, 2018). Thus, it is understandable that the hallmark of an open-ended approach is a learning approach that starts with giving open problems to students formulated with multiple correct answers or many appropriate solutions.

Regarding the relationship of open-ended approach to creative thinking, researchers have conducted research that says that: 1) math learning using an open-ended approach is very effective if applied to primary school students to deed and develop creative thinking skills (Waluyo, 2018); 2) learning with an open ended approach that can improve students' mathematical creative thinking skills (Firdaus et al., 2016); and 3) open-ended approach is able to have a positive influence on students' creative thinking skills (Amir, 2010). Based on the exposure of the results of studies that have been done by some 
of these researchers, it shows that the open-ended approach is able to influence the creative thinking abilities of students.

\subsubsection{Self Regulated Learning}

Self-reliance is the meaning of the word self-regulated learning. Zimmerman was the first academic to propose self -regulated learning in educational psychology. Self-regulated learning is a learning process in which students use self-regulation skills, such as self-assessment, self-directing, control and adjustment, in order to gain knowledge (Akbar et al., 2017). Self-regulated learning can be interpreted as an effort to conduct learning activities alone or with the help of others based on their own motivation to master a particular material and or competency so that it can be used to solve problems it encounters in the real world (Amir \& Risnawati, 2015). The concept of self-regulated learning is one of the important concepts in the theory of social learning. Self -regulated learning is a way of learning individually active students to achieve academic goals by controlling behavior, motivating themselves and using their cognitive in learning. In summary, self-regulated learning students can be observed the extent of their active participation in exerting metacognitive processes, motives and behaviors as they study.

Self-reliance is the attitude of a person who has knowledge of effective learning strategies and how and when to use his knowledge. Furthermore, a person who has self-reliance learns if able to manage his motivation that is motivation that comes from outside and from within him. Meanwhile, according to Masruri learning independence is an attitude formed due to the careful design of the learning process. The self-sustaining attitudes or behaviors formed here are deliberately formed and not self-formed.

Self-regulated learning is the ability of students to organize themselves in learning or also called student learning independence. In principle, self-regulated learning places importance on a person's ability to organize and control one's own, especially when facing a task. Self-regulated learning students, can be observed the extent of their active participation in exerting metacognitive processes, motivations and behaviors as they learn to learn (Hamundu et al., 2017). Based on that understanding, it can be concluded that self-regulated learning is part of the theory of cognitive learning that is closely related to behavior, motivation, and environment that can affect a person's achievements in learning.

Self-regulation learning is an activity to monitor and control the learning itself. Learning settings have several components, such as motivation, belief origin(epistemic)learning, metacognition, learning strategies, and prior knowledge. Motivation helps learners take the effort necessary to monitor and control learning. Epistemic beliefs are what learners believe about the nature of learning. Metacognition is thinking about the mind, which is the ability to understand what needs to be done in a given state (Reed \& Giessler, 1995). Corno and Mandinach divide the components of self-regulated learning into five important components grouped into two categories: 1) the process of obtaining information, which includes preparedness (receiving and following the path of information and monitoring; 2) the transformation process of the ability to select, connect, and plan (Setiani et al., 2018). Based on some of these opinions on the components of self-regulated learning, the four components of self-regulated learning include: 1) time; 2) strategy; 3) basic knowledge; and 4) trust.
The above four components describe the concept of self-arrangement which is a concept consisting of four main components namely time, strategy, basic knowledge and trust. Using these four plans will help students become self-reliant because it gives them a clear plan to improve their success in learning math and science, while also helping them to understand the integral relationship between knowledge, strategy and motivation. Without self-regulating skills, students will be at risk of despair or failure due to their learning problems and lack of ability. Individuals who apply self- regulated learning will experience a change in learning habits, namely by organizing and organizing themselves in such a way that it can determine the learning goals, learning needs, and strategies used in learning that leads to the achievement of goals that have been formulated. Self-reliance is a learning activity conducted by an individual with his freedom in determining and managing his/her own teaching materials, time, place, and utilizing the necessary learning resources. With the granting of freedom students have the ability to manage the way of learning, have a high sense of responsibility and are skilled at utilizing learning resources.

Zimmerman explained self-regulated learning indicators consist of: evaluation of the progress of the task, organizing the subject matter, making plans and learning objectives, seeking information, recording important things, regulating the learning environment, consequences after working, recurrence and recalling, asking peers, asking for help teachers/teachers, asking for adult help, recurring previous assignments or tests, repeating notes, recurring textbooks (Utari et al., 2018). Indicators of self-reliance of learning according to Sumarmo is as follows: (1) choose the purpose of learning; (2) resolve difficulties; (3) utilization of facilities; (4) cooperative nature; (5) building meaning and (5) self-control (Siregar, 2019). While according to Sumarmo the indicators of learning self-reliance are: (1) learning initiatives, (2) diagnosing learning needs, (3) setting targets and learning goals, (4) monitoring, regulating and controlling learning progress, (5) viewing difficulty as a challenge, (6) utilizing and finding relevant sources, (7) selecting and implementing learning strategies, (8) evaluating learning processes and outcomes and (9) having a self-concept (Siregar, 2019); (Setiani et al., 2018).

That attitude and creative thinking habits will essentially shape and foster self-regulated learning mathematics. Butler advises teachers should help students carry out a flexible and adactive self-regulated learning cycle by analyzing tasks, selecting and implementing strategies, monitoring themselves and reflecting (Meiliana \& Aripin, 2019). Self-learning is not self-learning. Self-regulated learning is considered to be able to make students get the expected grades, basically self-regulated learning if applied by the student personally will motivate the student not to stop learning and not rely on others in the learning process so that the student will receive the learning results as expected.

Improvement of the learning process to improve self-reliance and problem-solving skills can also be done by applying the right learning approach so that learning goals can be achieved. One of the steps that teachers can take to improve the learning independence of students is to provide learning in which open problems are presented both process and answer so as to invite students to hone their thinking skills. An approach is needed to convey learning that can improve students' attitudes or make students think positively, especially in math learning. Teachers can present nuanced learning of problem solving and 
constructivism as one of the efforts to improve students' creative thinking skills and learning independence. Such learning, among others, is math learning with an Open-Endedapproach. The Open-Ended approach promises an opportunity for students to investigate various strategies and ways they believe in accordance with their elaboration skills (Suriyani, 2015). Open ended approach in learning process can support improving self-regulated learning or student learning independence (Mahanani et al., 2019).

This statement is reinforced by the results of the study which said that: 1) there are differences in the effect of the application of problem-based learning with open ended approaches and problem-based learning without an open ended approach to improving the creative thinking skills of students who have high self-regulated learning (Akbar et al., 2017); 2) improved self-regulated learning of students taught using math learning with an Open-Ended approach better than those taught with conventional learning (Suriyani, 2015); and 3) improved self-regulated learning of students taught using math learning with an Open Ended approach is better than those taught with conventional learning (Suriyani et al., 2015). Based on the exposure of the results of the studies that have been conducted by some of these researchers, shows that the open-ended approach is able to influence the self-regulated learning of students.

\section{CONCLUSION}

Based on the results of riview conducted using library research method can be concluded that 1 . Learning mathematics using an open-ended approach affects the improvement of creative thinking skills and self-regulated learning of students, 2 . The open-ended approach is higher in improving students' creative thinking skills than using a convesional approach, 3. The open ended approach in learning has steps namely: a) teachers organizing students in learning activities; b) the teacher confronts the student on an open issue; c) teachers guide and direct students in solving problems with a variety of solutions and answers; d) students present the work and compare with the work of other students in front of the class; and e) students conclude lesson materials guided by the teacher, 4. To implement open-ended learning, it is necessary to prepare learning that requires high creativity for a teacher.

\section{REFERENCES}

Agustian, E., Sujana, A., \& Kurniadi, Y. (2015). Pengaruh Pendekatan Open-Ended Terhadap Kemampuan Berpikir Kreatif Matematis Siswa Sekolah Dasar Kelas V. Mimbar Sekolah Dasar, 2(2), 234-242.

https://doi.org/10.17509/mimbar-sd.v2i2.1333

Agustina, W., \& Noor, F. (2016). Hubungan Hasil Belajar dan Tingkat Berpikir Kreatif Siswa Dalam Pembelajaran Matematika. Math Didactic: Jurnal Pendidikan Matematika, 2(3), 191-200. https:// doi.org/10.33654/math.v2i3.49

Akbar, S., Kodirun, \& Busnawir. (2017). Pengaruh Pembelajaran Berbasis Masalah dengan Pendekatan Open ended terhadap Kemampuan Berpikir Kreatif Matematik Ditinjau dari Kemandirian Belajar Siswa SMA. Jurnal Pendidikan Matematika, 8(2), 117-128.

Amidi, \& Zahid, M. Z. (2016). Membangun Kemampuan Berpikir Kreatif Matematis Dengan Model Pembelajaran Berbasis Masalah Berbantuan E-Learning. Seminar Nasional Matematika X
Universitas Negeri Semarang 2016, 586-594.

Amir, Z. (2010). The Implementation of Mathematics Teaching with Open-ended Approach to UIN Suska Riau Mathematics Student's Ability of Mathematical Creative Thinking. Proceedings of the International Seminar on Mathematics.

Amir, Z., \& Risnawati. (2015). Psikologi Pembelajaran Matematika (1st ed.). Aswaja Pressindo.

http:/ / repository.uin-suska.ac.id/10388/1/Psikologi Pembelajaran Matematika.pdf

Amir, Z., \& Risnawati. (2014). Blog Development Based on Open-Ended. Prosiding the 2nd SEA-DR, 978, 426-431.

Andriani, Y. N., \& Madio, S. S. (2013). Perbandingan Kemampuan Berpikir Reflektif antara Siswa yang Mendapatkan Pendekatan Open-Ended dengan Konvensional. Mosharafa: Jurnal Pendidikan Matematika, 2(2), 135-144.

Ardiyanti, N. P. R., Suarjana, I. M., \& Garminah, N. N. (2013). Pengaruh Model Pembelajaran Matematika Berorientasi Open-Ended Problem terhadap Kemampuan Berpikir Kreatif Siswa pada Mata Pelajaran Matematika Kelas IV SD. Mimbar PGSD UNDIKSILA, 1(1).

https://ejournal.undiksha.ac.id/index.php/JJPGSD/article/vi ew/860

Dahlan, T., Nurhadi, M., \& Rohimah, S. M. (2017). Pengaruh Pendekatan Open-Ended terhadap Kemampuan Berpikir Kreatif Matematis Mahasiswa PGSD. Symmetry: Pasundan Journal of Research in Mathematics Learning and Education, 2(1), 53-66.

https:// doi.org/10.23969/symmetry.v2i1.381

Dinata, P. A. C., Rahzianta, \& Zainuddin, M. (2016). Self- Regulated Learning sebagai Strategi Membangun Kemandirian Peserta Didik dalam Menjawab Tantangan Abad 21. Seminar Nasional Pendidikan Sain, 1(1), 139-146.

Doncieux, S., Filliat, D., Díaz-Rodríguez, N., Hospedales, T., Duro, R., Coninx, A., M.Roijers, Di., Girard, B., Perrin, N., \& Sigaud, O. (2018). Open-Eended Learning: A Conceptual Framework Based on Representational Redescription. Frontiers in Neurorobotics, 12(1), 1-6.

https://doi.org/10.3389/fnbot.2018.00059

Faridah, N., Novianti, E., \& Kurniadi, Y. (2016). Pendekatan Open ended untuk Meningkatkan Kemampuan Berpikir Kreatif Matematis dan Kepercayaan Diri Siswa. Jurnal Pena Ilmiah, 1(1), 1061-1070.

ejournal.upi.edu/index.php/penailmiah/article/download/30 46/pdf

Febrianti, Y., Djahir, Y., \& Fatimah, S. (2016). Analisis Kemampuan Berpikir Kreatif Peserta Didik dengan Memanfaatkan Lingkungan pada Mata Pelajaran Ekonomi di SMA Negeri 6 Palembang. Jurnal Profit, 3(1), 121-127.

Firdaus, As'ari, A. R., \& Qohar, A. (2016). Meningkatkan Kemampuan Berpikir Kreatif Matematis Siswa SMA Melalui Pembelajaran Open-Ended Pada Materi SPLTV. Jurnal Matematika Statistika Dan Komputasi, 1(2), 227-236. https://doi.org/10.20956/jmsk.v15i2.5719

Firdausi, Y. N., Asikin, M., \& Wuryanto. (2018). Analisis Kemampuan Berpikir Kreatif Siswa Ditinjau dari Gaya Belajar pada Pembelajaran Model Eliciting Activities (MEA). FMIPA, Universitas Negeri Semarang, Semarang Usiyusrotin@gmail.Com, 1, 239-247.

Ginting, S. S. B. (2019). Peningkatan Kemampuan Berpikir Kreatif Matematis dan Kemandirian Belajar Siswa SMP Ar-Rahman Medan Melalui Pembelajaran Open-Ended Berbasis Brain-Gym. 
Axiom, 8(1), 26-40.

Hamundu, A., Sudia, M., \& Samparadja, H. (2017). Profil Pemecahan Masalah Terbuka yang Ditinjau dari Self- Regulated Learning Siswa SMP. Jurnal Pendidikan Matematika, 8(2), 148-158.

Japemar. (2019). Peningkatan Kompetensi Kognitif Matematika Siswa Menggunakan Pendekatan Open ended di Kelas X SMA Negeri 1 Ulakan Tapakis. Menara ILMU: Jurnal Penelitian Dan Kajian Ilmiah, 13(11), 28-32.

Kemendikbud. (2014). Materi Pelatihan Guru Implementasi Kurikulum 2013 Tahun Ajaran 2013/2014. Jakarta: Badan Pengembangan Sumber Daya Manusia Pendidikan dan Kebudayaan dan Penjamin Mutu Pendidikan.

Khaerobi, K. (2017). Pengaruh Pendekatan Open-Ended terhadap Kemampuan Komunikasi dan Self-Regulated Learning Peserta Didik Kelas IV Mata Pelajaran Ilmu Pengetahuan Alam (IPA) di MI Ismariah Al-Quraniyyah Rajabasa Bandar Lampung. Ekp, 13(3), 1576-1580.

Kurniati, R., \& Astuti, M. (2017). Penerapan Strategi Pembelajaran Open ended terhadap Kemampuan Berpikir Kritis Siswa pada Mata Pelajaran Matematika Kelas V di Madrasah Ibtidaiyah Negeri 1 Palembang. JIP: Jurnal Ilmiah PGMI, 2(1), 1-18.

Lestari, N., Hartono, Y., \& Purwoko. (2016). Pengaruh Pendekatan Open-Ended terhadap Penalaran Matematika Siswa Sekolah Menengah Pertama Palembang. Jurnal Pendidikan Matematika, 10(1), 81-95.

Lubis, R., Harahap, T., \& Nasution, D. P. (2019). Pendekatan Open-Ended dalam Membelajarkan Kemampuan Koneksi Matematis Siswa. Mosharafa: Jurnal Pendidikan Matematika, 8(3), 399-410.

Mahanani, D., Sutopo, \& Pramesti, G. (2019). Upaya Peningkatan Kemandirian Belajar dan Kemampuan Pemecahan (NHT) dengan Pendekatan Open-Ended pada Siswa Kelas XI SMKN 7. Jurnal Pendidikan Matematika Dan Matematika (JPMM), 3(1), 61-69.

Mahmoodi, M. H., Kalantari, B., \& Ghaslani, R. (2014). Self-Regulated Learning (SELF REGULATED LEARNING), Motivation and Language Achievement of Iranian EFL Learners. Procedia - Social and Behavioral Sciences, 98, 1062-1068. https://doi.org/10.1016/j.sbspro.2014.03.517

Meiliana, L., \& Aripin, U. (2019). Analisis Kemampuan Berpikir Kreatif dan Self-Regulated Learning Pada Siswa SMPN 1 Margaasih. Journal on Education, 1(4), 644-652.

Mihajlović, A., \& Dejić, M. (2015). Using Open-Ended Problems and Problem Posing Activities in Elementary Mathematics Classroom. The 9th International MCG Conference, 34-39.

https://www.mcg-9.net/pdfuri/MCG-9-Conference-proceedin gs.pdf\#page $=36$

Muhsinun. (2013). Pendekatan Open ended pada Pembelajaran Matematika. EDU-MAT: Jurnal Pendidikan Matematika, 4(2).

Muhtadi, D., \& Sukirwan. (2017). Implementasi Pendidikan Matematika Realistik (PMR) untuk Meningkatkan Kemampuan Berpikir Kreatif Matematik dan Kemandirian Belajar Peserta Didik. Mosharafa: Jurnal Pendidikan Matematika, 6(1), 1-12. http:/ /e-mosharafa.org/index.php/mosharafa\%0Ahttps://me dia.neliti.com/media/publications/226676-implementasi-pendi dikan-matematika-reali-9fd53b7a.pdf

Mursidik, E. M., Samsiah, N., \& Rudyanto, H. E. (2014). Analisis kemampuan berpikir kreatif siswa sd dalam memecahkan masalah matematika. LPPM, 2(1), 7-13.
MZ, Z. A. (2017). Strategi Metakognitif Dalam Pembelajaran Matematika. Jurnal Penelitian Dan Pembelajaran Matematika, 10(1), 60-67. https://doi.org/10.30870/jppm.v10i1.1198

MZ, Z. A., \& Muhandaz, R. (2019). Profil Kesulitan Belajar Matematika dan Self efficacy Matematis Siswa Sekolah Menengah di Riau. Suska Journal of Mathematics Education, 5(2), 141.

https:// doi.org/10.24014/sjme.v5i2.8254

Nahdi, D. S. (2017). Self-Regulated Learning Sebagai Karakter Dalam Pembelajaran Matematika. The Original Research of Mathematics, 2(1), 20-27.

Nurhikmayati, I., \& Sunendar, A. (2020). Pengembangan Project Based Learning Berbasis Kearifan Lokal Berorientasi pada Kemampuan Berpikir Kreatif dan Kemandirian Belajar. Mosharafa: Jurnal Pendidikan Matematika, 9(1), 1-12.

Palah, S., Maulana, M., \& Aeni, A. N. (2017). Pengaruh Pendekatan Open-Ended Berstrategi M-RTE terhadap Kemampuan Berpikir Kreatif Matematis Siswa Pada Materi Persegi Panjang. Pena Ilmiah, 2(1), 1161-1170.

Panjaitan, M. R. (2013). Pengaruh Model Inkuiri terhadap Hasil Belajar Matematika Ditinjau dari Kemandirian Belajar Siswa di SMP N Salatiga. Jurnal Ilmiah UKWS Salatiga, 2(2), 1-15.

Pehkonen, E., \& Helsinki. (1997). The State-of-Art in Mathematical Creativity. ZDM - International Journal on Mathematics Education, 29(3), 63-67. https://doi.org/10.1007/s11858-997-0001-z

Pintrich, P. R. (1999). The Role of Motivation in Promoting and Sustaining Self-Regulated Learning. International Journal of Educational Research, 31(6), 459-470.

https:// doi.org/10.1016/S0883-0355(99)00015-4

Priasmoro, D. P. (2016). Literatur Review:Aplikasi Model Sosial Dalam Pelayanan Kesehatan Jiwa Pada Ibu Hamil dengan Hiv/Aids. Jurnal Ilmu Keperawatan (Journal of Nursing Science), 4(1), 12-19. https://doi.org/10.21776/ub.jik.2016.004.01.2

Purwaningrum, J. P. (2016). Mengembangkan Kemampuan Berpikir Kreatif Matematis Melalui Discovery Learning Berbasis Scientific Approach. Refleksi Edukatika, 6(2), 145-157. https://doi.org/10.24176/re.v6i2.613

Putri, I. W. S., Hussen, S., \& Adawiyah, R. (2017). Kemampuan Berpikir Kreatif Dalam Menyelesaikan Masalah Kesebangunan di SMPN 11 Jember. Jurnal Edukasi, 4(3), 59-62.

https://doi.org/10.19184/jukasi.v4i3.6310

Putri, O. R. U. (2017). Pengembangan Buku Siswa Bercirikan Openended Mathematics Problem Untuk Membangun Berpikir Kreatif. Jurnal Silogisme: Kajian Ilmu Matematika Dan Pembelajarannya, 2(1), 7-14.

https://doi.org/10.24269/js.v2i1.502

Rahmazatullaili, Zubainur, C. M., \& Munzir, S. (2017). Kemampuan berpikir kreatif dan pemecahan masalah siswa melalui penerapan model project-based learning. Beta Jurnal Tadris Matematika, 10(2), 166-183. https://doi.org/10.20414/ betajtm.v10i2.104

Reed, W. M., \& Giessler, S. F. (1995). Prior Computer-Related Experiences and Hypermedia Metacognition. Computers in Human Behavior, 11(3-4), 581-600. https://doi.org/10.1016/0747-5632(95)80018-4

Rientiesa, B., Tempelaar, D., Nguyen, Q., \& Littlejohn, A. (2019). Unpacking the Intertemporal Impact of Self-Regulation in A Blended Mathematics Environment. Computers in Human Behavior, 100, 345-357.

https://doi.org/10.1016/j.chb.2019.07.007 
Rudyanto, H. E. (2016). Pengembangan Kreativitas Siswa Sekolah Dasar Melalui Pembelajaran Matematika Open-Ended. Premiere Educandum: Jurnal Pendidikan Dasar Dan Pembelajaran, 3(02), 184-192.

https:// doi.org/10.25273/pe.v3i02.275

Ruslan, A. S., \& Santoso, B. (2013). Pengaruh Pemberian Soal Open-Ended Terhadap Kemampuan Penalaran Matematis Siswa. Kreano: Jurnal Matematika Kreatif-Inovatif, 4(2), 138-150. https:// doi.org/10.15294/ kreano.v4i2.3138

Samo, D. D. (2016). An Analysis of Self-Regulated Learning on Mathematics Education Student FKIP Undana. Infinity Journal of Mathematics Education, 5(2), 67-74.

https://doi.org/10.22460/infinity.v5i2.213

Sari, K. P., Neviyarni, \& Irdamurni. (2020). Pengembangan Kreativitas dan Konsep Diri Anak SD. Jurnal Ilmiah Pendidikan Dasar, 7(1), 44-50.

Sariningsih, R., \& Herdiman, I. (2017). Mengembangkan Kemampuan Penalaran Statistik dan Berpikir Kreatif Matematis Mahasiswa di Kota Cimahi Melalui Pendekatan Open-Ended. Jurnal Riset Pendidikan Matematika, 4(2), 239-246.

https://doi.org/10.21831/jrpm.v4i2.16685

Setiani, N., Santoso, B., \& Kurjono. (2018). Self-Regulated Learning and Achievement Motivation To Student Academic Procrastination. Jurnal Manajerial, 3(4), 17-38. https:// doi.org/10.17509/manajerial.v17i1.9759

Siregar, T. J. (2019). Peningkatan Kemandirian Belajar Siswa SMP Melalui Pembelajaran Berbasis Masalah. AXIOM, 8(2), 203-213.

Soekarno Putri, M. (2003). Undang-Undang Republik Indonesia Nomor 20 Tahun 2003 tentang Sistem Pendidikan Nasional dengan Rahmat Tuhan Yang Maha Esa.

Soeyono, Y. (2013). Mengasah Kemampuan Berpikir Kritis dan Kreatif Siswa Melalui Bahan Ajar Matematika dengan Pendekatan Open-Ended. Seminar Nasional Matematika Dan Pendidikan Matematika FMIPA UNY, 639-648.

Suhandri. (2013). Meningkatkan Kemampuan Berpikir Kreatif Matematis Siswa melalui Pendekatan Open-ended. Gamatika, 3(2), 242586.

Suherman, R. (2019). Analisis Kemampuan Berpikir Kritis Siswa Dalam Pemecahan Masalah Matematika Melalui Pendekatan Open-ended Problem. Prosiding Seminar Nasional \& Call-For Papers, 3(2), 482-488. https:// doi.org/10.30998/jkpm.v3i2.2768

Suriyani. (2015). Peningkatan Kemampuan Berpikir Kreatif dan Kemandirian Belajar Siswa MTs Negeri 2 Medan Melalui Pembelajaran Matematika dengan Pendekatan Open-Ended. Edu Science, 2(2), 28-34.

Suriyani, Hasratuddin, H., \& Asmin, A. (2015). Peningkatan Kemampuan Berpikir Kreatif dan Kemandirian Belajar Siswa MTs Negeri 2 Medan Melalui Pembelajaran Matematika dengan Pendekatan Open-Ended. Jurnal Tabularasa, 12(3). https://doi.org/10.24114/jt.v12i3.3251

Susilo, H. (2015). The Development of Some 21st Century Skills through Lesson Study-based Classroom Action Research to Improve the Teaching Learning Quality of Plant Physiology Course. Prosiding Seminar Nasional Pendidikan Biologi 2015, 729-741.

Utami, R. W., Endaryono, B. T., \& Djuhartono, T. (2020). Meningkatkan Kemampuan Berpikir Kreatif Matematis Siswa Melalui Pendekatan Open Ended. Faktor Jurnal Ilmiah Kependidikan, 7(1), 43-48.

https://doi.org/https://doi.org/10.17509/edusentris.v3i3
Utari, A., Senen, S. H., \& Rasto. (2018). Pengaruh Self-Regulated Learning (Slr) Terhadap Prestasi Belajar Siswa Pada Mata Pelajaran Ekonomi. SOSIO-DIDAKTIKA: Social Science Education Journal, 5(1), 8-14. https://doi.org/10.15408/sd.v1i1.9521

Wahyudi, I., \& Marsidin, S. (2019). Pengaruh Pendekatan Open ended dan Motivasi Belajar terhadap Hasil Belajar Matematika Siswa di Kelas V SD. Jurnal Basicedu, 3(3), 924-929.

Waluyo, A. (2018). Pengaruh Pendekatan Open-Ended terhadap Kemampuan Berpikir Kreatif Siswa Dalam Mata Pelajaran Matematika di Sekolah Dasar. Jurnal Pendidikan Sekolah Dasar, 5(1), 105-119. https://doi.org/10.12928/jpsd.v5i1.12571

Wanelly, W., \& Fauzan, A. (2020). Pengaruh Pendekatan Open-Ended dan Gaya Belajar Siswa terhadap Kemampuan Berpikir Kreatif Matematis. Jurnal Basicedu, 4(3), 523-533. https:// doi.org/10.31004/ basicedu.v4i3.388

Widiawati, Fuadiyah, S., Syamsurizal, \& Ardi. (2019). The Analysis of Creative Thinking Ability of VII Class Student in Biology Learning at SMPN 25 (Junior High School 25) Padang. Atrium Pendidikan Biologi, 4(4), 75-84.

Yuliana, E. (2015). Pengembangan Soal Open ended pada Pembelajaran Matematika untuk Mengidentifikasi Kemampuan berfikir Kreatif Siswa. In Seminar Nasional Pendidikan Matematika (SNAPTIKA).

Zarkasyi, W. (2015). Penelitian Pendidikan Matematika. Refika Aditama. 